\title{
Earthquake awareness and perception of risk among the residents of Istanbul
}

\author{
Sıdıka Tekeli-Yeşil • Necati Dedeoğlu • \\ Charlotte Braun-Fahrlaender • Marcel Tanner
}

Received: 29 March 2010/ Accepted: 26 February 2011/Published online: 20 March 2011

(C) Springer Science+Business Media B.V. 2011

\begin{abstract}
Awareness and perception of risk are among the most crucial steps in the process of taking precautions at individual level for various hazards. In this study, we investigated the factors affecting better knowledge and greater risk perception about earthquakes among residents of Istanbul. A field survey was carried out, and a total of 1,123 people were interviewed in two districts of Istanbul with different seismic risk levels and from three (low, moderate and high) socio-economic levels (SEL). The findings showed that although the level of knowledge regarding earthquakes and preparedness for them was promising, it could be improved. The results indicated that future preparedness programmes should target people with lower educational and socio-economic levels. The media were the leading source of information among the respondents. Location of the home was a strong influence on individuals having above average earthquake knowledge and even more on high risk perception. Socio-economic parameters (educational level, economic status, SEL of the sub-district and tenure of the home), gender and attitude score were other factors influencing greater risk perception with regard to earthquakes.
\end{abstract}

Keywords Earthquake hazards · Disasters · Awareness · Risk perception · Istanbul

\section{Introduction}

Of all the natural hazards, the greatest threat to Turkey is earthquakes. Between 1980 and 2009, 20,495 people were killed and 5,925,161 were affected by earthquakes (EM-DAT 2009). It is, therefore, vital that not only governmental and local authorities but also individuals should take action to mitigate damage and to prepare themselves. Individuals can reduce the impact of an earthquake and protect themselves, their families and homes

S. Tekeli-Yeşil $(\bowtie) \cdot$ C. Braun-Fahrlaender $\cdot$ M. Tanner

Department of Epidemiology and Public Health, Swiss Tropical and Public Health Institute,

Socin Str. 57, P.O. Box 4002, Basel, Switzerland

e-mail: sidikatekeli@hotmail.com; sidika.tekeli-yesil@unibas.ch

N. Dedeoğlu

Medical Faculty Department of Public Health, Akdeniz University, Antalya, Turkey 
by taking measures such as fixing high furniture securely or obtaining earthquake insurance. Despite the effectiveness of such measures, people in both developing (Dedeoğlu 2006; Kalaça et al. 2007) and developed countries (Lehman and Taylor 1987; Lindell and Prater 2000) often fail to adopt them. The findings of our two previous studies, a quantitative study (Tekeli-Yeşil et al. 2010a) and a qualitative one (Tekeli-Yeşil et al. 2010b), in Istanbul indicated that risk awareness is one of the most crucial factors in the process of taking such action. The findings of the qualitative study showed that the amount of knowledge of the risk and its consequences were considerable, and participants presented a realistic appraisal of the risk. In general, however, participants were less well informed about how to cope with an earthquake at individual level. On the other hand, the quantitative study indicated earthquake knowledge variables among the important factors predicting the likelihood of preparing for an earthquake. Even though risk perception is an indirect factor in the process of taking action, many studies point to its importance (Solberg et al. 2010). This paper, therefore, examines the factors associated with enhanced perception of and awareness about the risk in Istanbul, where an earthquake with a magnitude greater than 7 on the Richter scale is expected at any time within 30 years with a $62 \%$ $( \pm 15 \%)$ probability (Parsons et al. 2000).

\subsection{Background}

In previous studies, knowledge of a hazard and determinants of such knowledge were not studied as much as risk perception and its determinants. Hurnen and McClure (1997) found a significant correlation between earthquake knowledge scores and preparation scores, which showed that those with more knowledge about earthquakes were more likely to have prepared for one. In Lindell and Whitney's (2000) study, respondents' ratings of their own knowledge about the hazard were significantly correlated with intentions to adopt mitigation and preparedness measures, and self-reported behaviour. Knowledge about earthquakes was also found to be significantly associated with a completed prevention score in Fişek et al.'s study (2003). Nevertheless, these studies did not investigate the factors affecting knowledge about earthquakes. Burningham et al.'s (2008) study about flood awareness found that area of residence, experience of flooding, length of residence, tenure and social class were factors predicting the likelihood of awareness about floods.

Slovic et al. (2000) noted that perceived risk, which referred to various kinds of attitude and judgment about a risk, is quantifiable and predictable. They argued that perceived risk could be predicted from knowledge of an item's considered dread and severity and closely related to a potential threat to future generations, potential for global catastrophe, personal threat and inequity.

Public perceptions are usually the product of intuitive biases and economic interests and reflect cultural values Kasperson et al. (2000), while experts' expressions of risk are based on objective, analytic and rational risk assessments. In addition to the real risk, it is important how the public judge it, because people respond to the hazards they perceive and many factors underline those perceptions Slovic et al. (2000).

Even though some authors have found associations between risk perception and the taking of preventive measures (Kalaça et al. 2007), others have discussed that there is only an indirect link between risk perception and the taking of preventive measures (Lindell and Whitney 2000; Mileti and Fitzpatrick 1992). Factors associated with the perception of various risks include area of residence or actual hazard risk level (Davis et al. 2005; Fişek et al. 2003; Lindell and Prater 2000), personal experience of a hazard (Davis et al. 2005; Lin et al. 2008; Lindell and Prater 2000; Weinstein 1989) or post-traumatic stress 
symptoms (Davis et al. 2005; Fişek et al. 2003; Lindell and Prater 2000), characteristics of a hazard or its impact (Ho et al. 2008; Lindell 1994; Paton et al. 2001) and gender (Armaş 2008). Mileti and Fitzpatrick (1992) stated that risk communication factors such as salience and the style and frequency of messages are also important factors in the perception of risk.

In the case of Istanbul, the level of knowledge about the predicted earthquake among the inhabitants of Istanbul is quite high. The study of Fişek et al. (2003) showed respondents giving a realistic appraisal of the risk they face in terms of the security of their zones. In the same study, 75 per cent of the respondents gave relevant answers to the question 'What is an earthquake?', and 62 per cent saw the construction of their homes as the real source of danger. However, when it came to preparing for an earthquake or mitigating the consequent damage, people showed less, and in some cases only superficial knowledge of what to do to. Their knowledge was usually derived from statements made by scientists in the media (Tekeli-Yeşil et al. 2010b). Additionally, people can access the information about risk zones of the city on the web pages of various institutions and the municipality. This information has had also wide coverage in the media. Many inhabitants of Istanbul had already experienced earthquakes before (Bay Aytekin 2006; IBB 2002) and had a high perception of the risk of a predicted earthquake. According to studies conducted in different districts of Istanbul, over 50 per cent of the respondents perceived a high risk of a predicted earthquake: 68.8 per cent (Kalaça et al. 2007); 52.5 per cent (Işeri Say et al. 2005); 58.3 per cent (IBB 2002); and 58.1 per cent (T.C. Başbakanlık PUB 2005). However, risk perception declines when the question is referred from the city to the individual level (Işeri Say et al. 2005).

\subsection{Rationale of this study}

As mentioned earlier, even though the association between knowledge and action has been studied in some way, there is limited information about the factors affecting knowledge of the risk and how to cope with it. A previous study (Tekeli-Yeşil et al. 2010a) showed that the latter especially is important in the process of taking action. Therefore, in this paper, we aimed to identify the factors predicting knowledge about an earthquake and about how to cope with its consequences. Considering the links between knowledge, education and SEL, and the dominant role of actual risk level (area of residence) in the process of taking action, we hypothesised that there would be differences in the level of knowledge about earthquakes and how to cope with the consequences between respondents living in lower- and higher-risk areas and among SEL.

Additionally, the literature noted in the previous section indicates area of residence or actual hazard risk as a factor associated with perception of the risk. However, the national studies looked at the association between taking action and risk perception, but did not investigate the determinants of greater perceptions of risk.

\section{Methodology}

The data reported here are taken from a survey conducted in 2007, whose results were partly reported by Tekeli-Yeşil et al. (2010a). The study was conducted in Istanbul, Turkey. Scientists forecast that a major earthquake with a $62 \%$ probability $( \pm 15 \%)$ could happen in the vicinity of Istanbul before 2030 (Parsons et al. 2000). According to seismic risk assessments, the intensity distribution of the predicted earthquake would vary from district to district and range from 5.5 to 10.0 (BU 2003). On this basis, we selected two 
districts of Istanbul, Bakırköy and Beykoz, as research sites: Bakırköy is expected to be among the districts to experience the highest intensity $(9.0-9.5)^{1}$ and Beykoz to be among those experiencing the lowest intensity (5.5-6.0) (BU 2003).

A field survey was carried out, and a total of 1,123 people were interviewed in these districts in May and June 2007. We used a stratification process in the survey, categorizing the sub-districts (mahalles) of these two districts according to SEL. The assessment of high, moderate or low SEL was based on information on economic level of the residents and cost of housing in the sub-districts, which we gathered from the district administrations through interviews. Considering this information, sub-districts were categorised as high, moderate or low SEL on the districts' maps with senior officers of the related departments. After the stratification process, households were selected randomly from each stratum by a two-stage cluster sampling technique.

\subsection{Dependent variables}

\subsubsection{Awareness}

Respondents were asked three questions to assess their awareness of earthquakes. The first was about what an earthquake is: respondents could choose answers ranging from scientific to religious explanations or other explanations such as a consequence of solar/lunar eclipse, or give answers in their own words which we categorized later. The second question was about knowledge regarding possible mitigation and preparedness measures, to which we recorded respondents' spontaneous answers. A list corresponding to the measures suggested in earthquake preparation leaflets, such as the Civil Defence Organization (CDO) leaflet (CDO 2009), was prepared in advance but not read to the respondents. If the spontaneous answer matched any item on the prepared list, the interviewer ticked the matching item or items. Additional measures mentioned by the respondent were recorded as verbatim and categorized later. The third question was about how to behave during an earthquake. Respondents chose answers ranging from 'don't know' to 'drop to the ground, take cover under a sturdy table or other piece of furniture, and hold on until the shaking stops' (this last taken from information booklets).

\subsubsection{Risk perception}

Risk perception was explored by six statements about perception of earthquake risk. Respondents were asked to agree or disagree (on a three-point scale) with statements about how they perceived the risk of an earthquake. In order to assess how the respondents judge the seismic risk of the location of their home, two statements about the seismic risk of the district and sub-district were provided. These two measures were combined into a compound measure of risk perception regarding location of the home $(\alpha=0.76)$. A person was categorized as perceiving a high risk regarding location of his/her home if he/she considered the district or the sub-district more risky than other districts or sub-districts. Respondents were also asked whether they or their families would suffer from the consequences of an earthquake and whether they saw the buildings they were living in as at

\footnotetext{
${ }^{1}$ Only in the Adalar district is the intensity expected to be higher (9.0-10.0) than in Bakırköy. This district was not considered during the selection as it is composed of small islands in the Marmara Sea that are mainly occupied during the summer.
} 
risk of damage due to an earthquake. In addition, they were asked whether they agreed or disagreed with the statement 'I am more worried about other threats/risks in daily life'.

\subsection{Explanatory variables}

Demographic variables were gender $($ male $=0$, female $=1)$, age $(16-34$ years, $35-54$ years, $\geq 55$ years), presence of a child at home (no $=0$, yes $=1$ ), marital status ( married $=1$, unmarried $=0)$ and location of the home $($ Bakirkoy $=1$, Beykoz $=2)$. Socio-economic variables were self-expressed economic level (high $=3$, moderate $=2$, low $=1$ ), SEL of the sub-district (high $=3$, moderate $=2$, low $=1$ ), educational level (graduate of a university or an institution of higher education $=3$, middle or high school $=2$, illiterate/literate, primary school $=1$ ) and tenure $($ owner $=1$, others $=0)$. Experience of an earthquake was assessed with three items (all measured no $=0$, yes $=1$ ): whether the respondent had ever experienced an earthquake; whether the respondent or a member of his/her family had experienced damage or injury in past earthquakes; or whether the respondent had participated in solidarity and/or rescue activities after a past earthquake. Respondents' attitudes towards the taking of measures against an earthquake were assessed with 11 items addressing attitudes towards different types of measure such as structural and non-structural measures and micro- and macro-level measures, fatalism regarding earthquakes and actors in disaster management. These items were combined into a compound measure of attitudes towards action score $(\alpha=0.63)$. Attitudes such as belief in the effectiveness of measures, which motivate adjustment behaviours and do not constitute major obstacles to disaster risk reduction efforts, were considered as action-stimulating behaviour. Attitudes such as fatalism, which reduce or obviate the motivation to take warnings seriously and the intention to engage in adjustment behaviours (Solberg et al., 2010), were considered as not stimulating behaviour. (Respondent showed at least 7 actionstimulating attitudes $=1$, respondent showed fewer than 7 action-stimulating attitudes $=0$.) In addition, respondents' general safety practices were assessed through the use of safety belts while travelling in a car in the previous month (never/seldom $=0$, no such situation $=1$, often/always $=2$ ). Awareness and risk perception were also considered as explanatory variables for each other. Additionally, in order to find out the discrepancies between respondents' subjective appraisals and their objective situations about risk in the location of their homes and the homes themselves, we made two comparisons using following variables. (i) Respondents' perception of risk regarding the district they were living in was compared with a computed variable about respondents' objective and subjective risk assessments considering their districts. This variable was computed by combining the actual risk level of the district in which the respondents were living with their perception of the risk. For example, the answer of a respondent living in Bakırköy and perceiving his/her district as risky was coded as 'objective risky'. If he/she was living in Beykoz, the answer was coded as 'subjective risky'. (ii) Respondents' risk perceptions considering eventual damage to their homes were compared with the objective situation of their homes. We assessed the objective situation of the home by means of the following questions: 'Have you had the building tested for construction quality (earthquake resistant)?' $(0=$ No or do not know, $1=$ Yes); 'Have you done anything if the tests showed that the building was not resistant?' ( $1=$ the building was resistant, $2=$ No, $3=$ Yes, $4=$ don't know). The survey included another question asking by whom the construction quality has been tested. This was asked as a control question. If the respondent said that the home had been tested but gave an impossible answer as to who had tested it - for example, the name of an institution not responsible for such tests-his/her answer was coded as 0 . If the respondent had had the 
building tested for construction quality and tests had shown that either it was earthquake resistant according to current building codes or it had been retrofitted in case of a negative result, the objective situation of the home was coded as 'not risky'. All other combinations were coded as 'risky'. These variables were only used for descriptive information and not used in the univariate and multivariate analysis.

\subsection{Analysis}

For descriptive information, frequency analysis and cross-tabulations were made. For cross-tabulations, statistical significance was determined using the chi-square test. The association between taking action and independent variables was assessed in a univariate analysis. The results of this analysis are expressed as odds ratios (OR) and their 95\% confidence intervals (CI). A multivariate logistic regression analysis was then made, using the option forward LR (log likelihood ratio) in the logistic regression command. In order to explore the effect of factors on each other and the changes in ORs, the variables were entered sequentially. All the results of univariate and multivariate analysis are presented to show these changes. The reason for presenting final models with all the variables was to be able to see the changes in the impacts of factors with the introduction of new factors. That was also the reason for entering variables sequentially.

Detailed information about the data collection process, the questionnaire and analysis is set out elsewhere (Tekeli-Yeşil et al. 2010a).

\section{Results $^{2}$}

\subsection{Awareness: knowledge of the risk, its consequences and how to cope with it}

Scientific explanations about what an earthquake is were given by $58 \%$ of the respondents; religious explanations (act of God) were given by 18\%, and mixed (scientific and religious) explanations by $14 \%$ (Fig. 1).

Of the respondents, $18 \%$ could mention spontaneously at least two (mean: 1.7, SD: 1.6) of the nine measures listed in the questionnaire for the knowledge score, $14 \%$ could not spontaneously mention any of them and only $2 \%$ spontaneously mentioned all of them. The most frequently mentioned measure $(67 \%)$ was to obey the most recent building codes and thus live in a well-built, earthquake-resistant house; the least commonly mentioned measure (3\%) was to have a fire extinguisher and learn how to use it (Fig. 2).

While $55 \%$ of the respondents chose the answer taken from information booklets for the question about how to behave during an earthquake, $3 \%$ said that they did not know how to behave during an earthquake (Fig. 3).

We asked about the source of information regarding earthquakes and how to cope with them. The leading source was the media: $89 \%$ of the respondents said that they got their information from television and $48 \%$ from newspapers or magazines; $2 \%$ said that they had not received any information (Table 1).

Table 2 displays the results of the univariate analysis of the factors significantly associated with giving a scientific explanation about what an earthquake is or being able to mention at least two measures spontaneously or knowing what to do in an earthquake. As could be expected, educational level and SEL of the sub-district were the leading factors

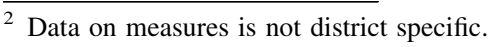


Fig. 1 Knowledge about the cause of an earthquake

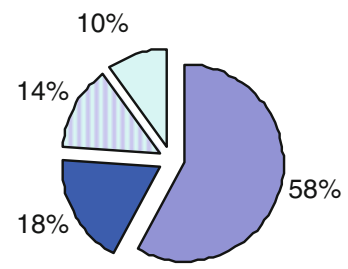

$\square$ Scientific explanation

Q Religious explanation

$\square$ Scientific + religious explanation $\square$ Others/other combinations

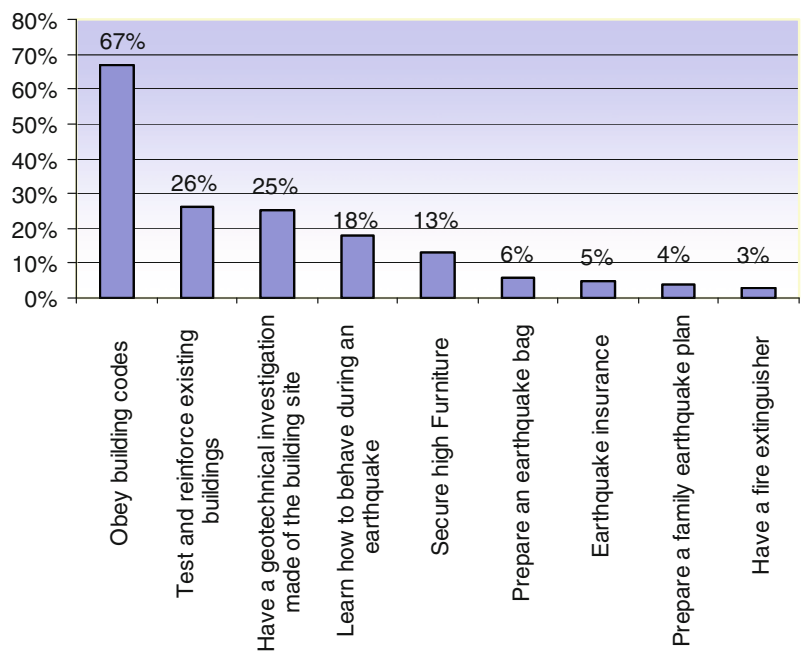

Fig. 2 Knowledge about the mitigation and preparedness measures

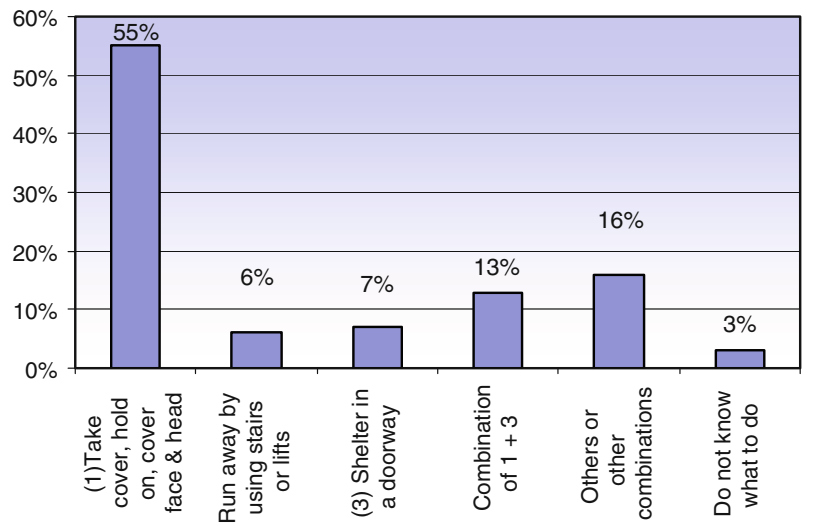

Fig. 3 Knowledge about what to do during an earthquake 
Table 1 Source of information about the risk and how to cope with it

a Multiple choices were possible

\begin{tabular}{lrr}
\hline Source of information $^{\mathrm{a}}$ & $N$ & $\%$ \\
\hline Television & 985 & 89 \\
Newspapers or magazines & 536 & 48 \\
Internet & 206 & 18 \\
School, workplace, neighbourhood activities & 149 & 13 \\
Non-governmental and community-based organizations & 133 & 12 \\
Official institutions & 117 & $10 \%$ \\
Friends, neighbours, relatives & 113 & 10 \\
Have not received such information & 27 & 2 \\
\hline
\end{tabular}

associated with all three dependent variables. Tenure was not significantly associated with any of them, but attitude and general safety scores were commonly associated with them. Two of the variables about experience with earthquakes (the respondent had experienced only the phenomenon or had experienced injury/damage due to earthquakes in the close circle) did not show any significant association at all. Among the risk perception variables, being more worried about other threats/risks in daily life showed no significant association with any of the dependent variables. Among demographic factors, gender and marital status were not significantly associated with any of the dependent variables.

\subsubsection{Knowledge about what an earthquake is}

Educational level, self-expressed economic status, SEL of the sub-district, location of the home, attitude score, general safety score, age and presence of a child at home were significantly associated (in that order) with the giving of scientific explanations about what an earthquake is. Among the risk perception variables 'believing that the building is strong' and perceiving a risk for self and the family showed a weak significant association with the giving of a scientific explanation about what an earthquake is.

\subsubsection{Knowledge about mitigation and preparedness measures}

Even though location of the home was associated with the giving of a scientific explanation about what an earthquake is and knowing what to do in an earthquake, it did not show a significant association with the spontaneous mention of at least two measures. Socioeconomic factors, educational level, self-expressed economic status and SEL of the sub-district were the three leading factors significantly associated with the spontaneous mention of at least two measures. Other factors significantly associated with the spontaneous mention of at least two measures were a belief that the building was strong, having a higher attitude score, participation in solidarity and rescue activities in previous earthquakes, and having a higher general safety score.

\subsubsection{Knowledge about what to do in an earthquake}

Socio-economic factors: self-expressed economic status, educational level and SEL of the sub-district were the three leading factors significantly associated with knowing what to do in an earthquake, followed by having a higher attitude score, believing that the building was strong, location of the home and having a higher general safety score. 


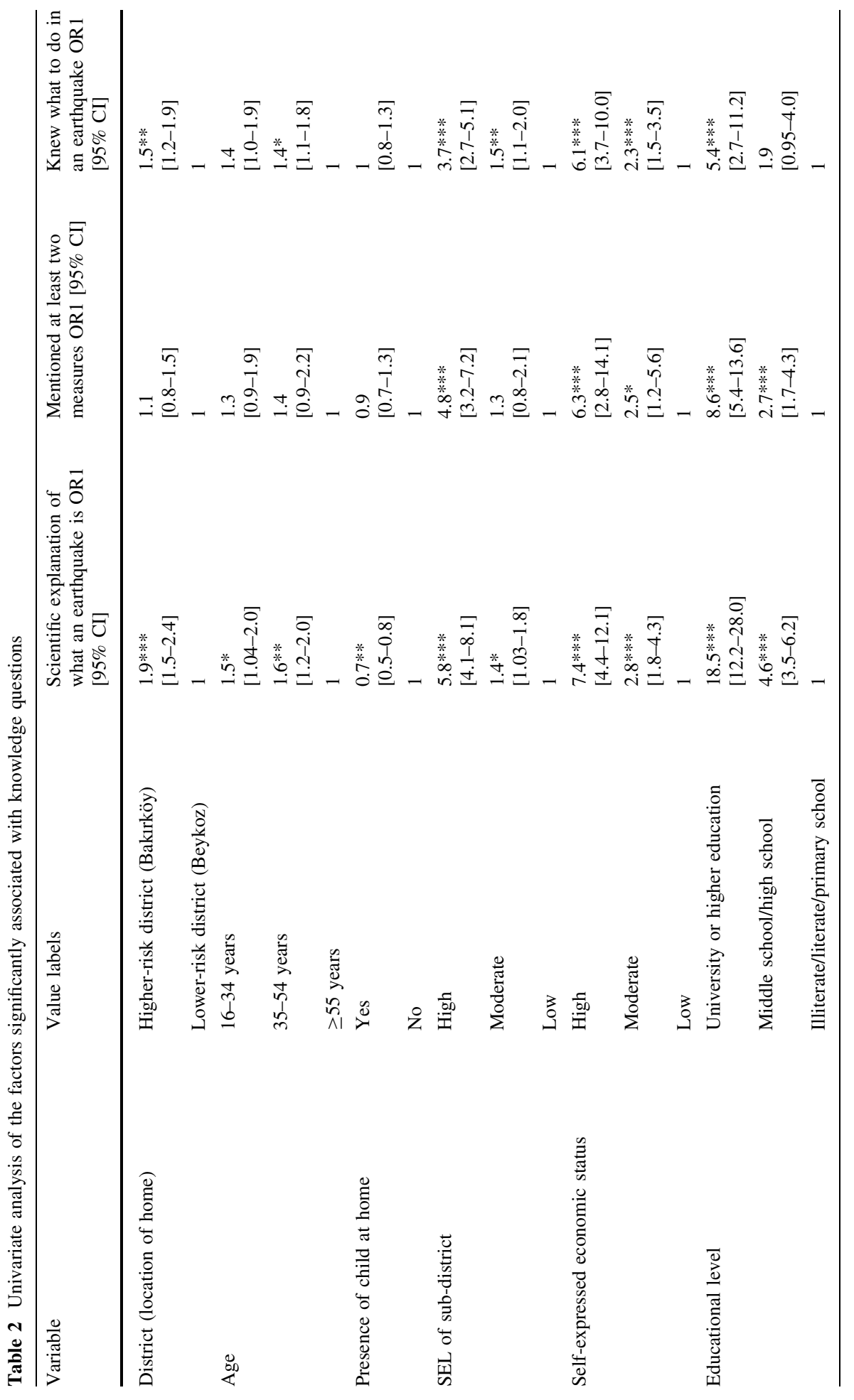




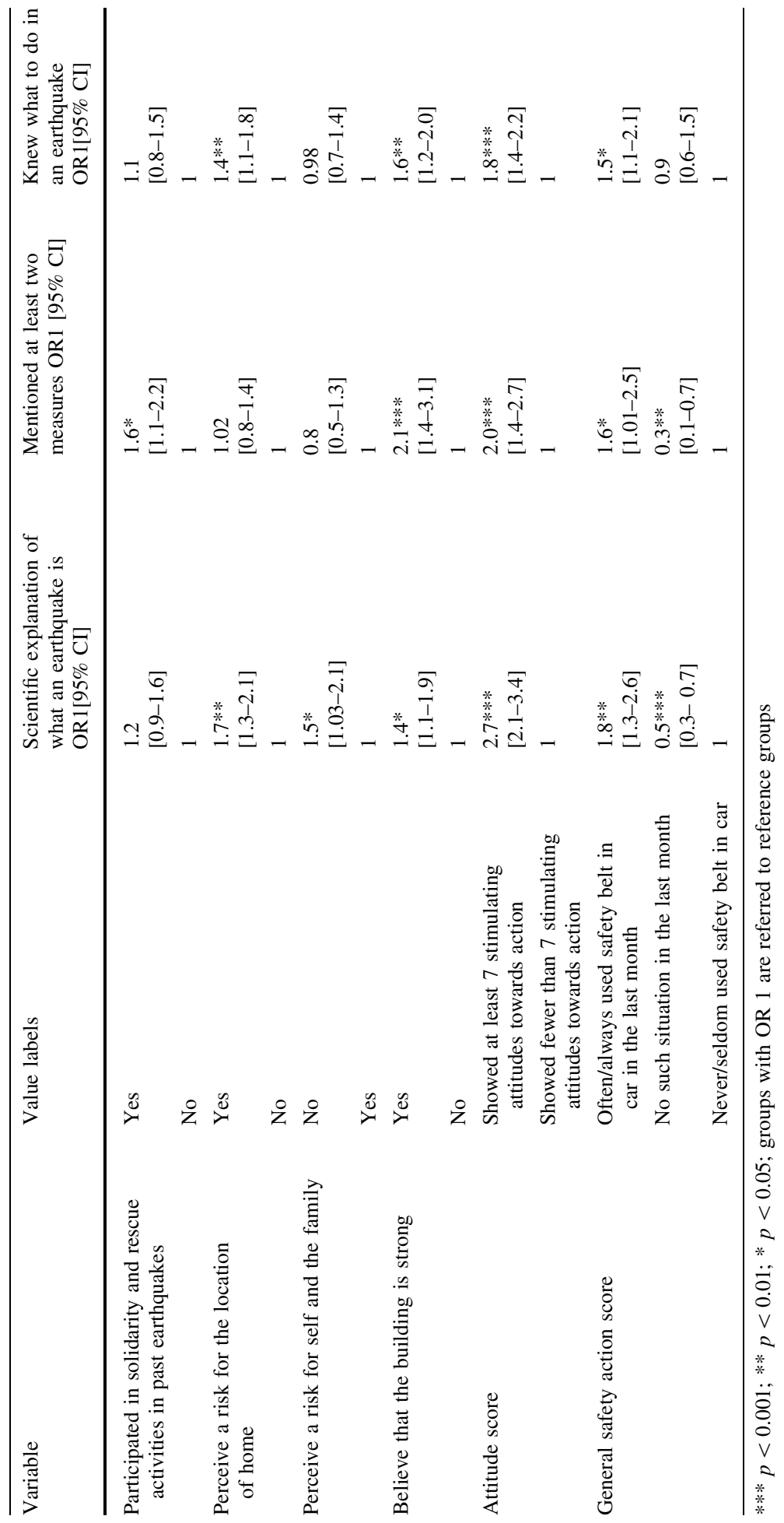


Multivariate logistic regression analysis (Table 3) showed that educational level and SEL of the sub-district have the greatest influence on all of the three knowledge parameters. The impact of educational level was the highest on scientific explanation about what an earthquake is. Location of the home was also influential on a scientific explanation about what an earthquake is, but it showed a weak association with knowing what to do in an earthquake and it did not show a significant association with spontaneously mentioning at least two measures. The impact of age groups on giving a scientific explanation about what an earthquake is was altered with the introduction of educational level to the model, and age (being in the middle-age group) showed only a weak significant association at the end. Age did not show any significant association with spontaneously mentioning at least two measures and knowing what to do in an earthquake in the multivariate analysis. Presence of a child at home showed only a weak significant association with giving a scientific explanation. The attitudes score was significantly associated with giving a scientific explanation about what an earthquake is, but not with other knowledge parameters. Perceiving risk for self and the family was significantly associated with being able to mention spontaneously at least two measures.

\subsection{Perception of the risk}

Of the respondents, $81 \%$ gave realistic risk appraisals regarding the district they were living in, meaning that their risk perceptions were parallel with the actual risk level of the district; $34 \%$ of their answers showed that they considered their district objectively as risky, $4 \%$ considered them subjectively as risky; $47 \%$ considered them objectively as not risky and $16 \%$ considered them subjectively as not risky. For example, only $15 \%$ of the respondents living in Bakırköy (the higher-risk area) thought that their district had a lower earthquake risk than other districts. However, when the focus was narrowed to the subdistrict, family/self and the home, the risk perception of the respondents living in Bakırköy decreased, while that of the respondents living in Beykoz slightly increased. There was no significant difference between Bakırköy and Beykoz residents regarding their responses to the question about the resistance of their homes to earthquakes (Table 4).

Thirty-one per cent of all the respondents had objective criteria for their judgements about the earthquake resistance of their homes, while $43 \%$ had no objective criteria. Of the respondents who perceived that their homes would not suffer damage due to an earthquake, $57.5 \%$ had no objective criteria for their judgement; $42.5 \%$ of these respondents had had the buildings tested for construction quality, and these tests had indicated that their buildings were earthquake resistant according to current building codes, or the required retrofitting had been completed. The difference between subjective appraisals and objective situation about the earthquake risk of the home was statistically significant $\left(p<0.001, \chi^{2}\right)$.

The majority of the respondents in both districts (70\% in Bakırköy and 69\% in Beykoz) mentioned that they were more worried about other threats in daily life, and there were no significant differences in their statements.

In order to assess the perceptions of the respondents about the general damage in destructive earthquakes, respondents were asked to guess the percentage of buildings that totally collapsed in the city of Izmit during the earthquake of 17 August 1999. ${ }^{3}$ Izmit was severely affected during the earthquake and has a similar building stock to Istanbul. In the

\footnotetext{
3 The question is taken from a test applied to the participants in a disaster preparedness education programme conducted by the Disaster Preparedness Education Unit of Boğaziçi University Kandilli Observatory and Earthquake Research Institute.
} 
Table 3 Multivariate logistic regression analysis of the factors predicting the likelihood of having enhanced knowledge regarding earthquake preparedness

Scientific explanation Mentioned at least two Knew what to do of what an earthquake is measures (spontaneously) in an earthquake OR; $[95 \% \mathrm{CI}]$ $\mathrm{OR} ;[95 \% \mathrm{CI}]$ OR; [95\% CI]

\section{Location of the home}

Higher-risk area (Bakırköy)

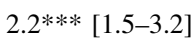

Presence of child at home

Yes

No

$$
0.7 *[0.5-0.9]
$$

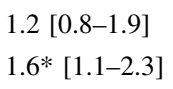

Self-expressed economic status

High
Moderate
Low

$$
\begin{aligned}
& 1.7[0.9-3.1] \\
& 1.5[0.9-2.4]
\end{aligned}
$$

SEL of the sub-district

High
Loderate

\section{Educational level}

University or higher education

Middle school/high school

$$
\begin{aligned}
& 2.6 * * *[1.7-4.0] \\
& 1.4 *[1.01-2.0] \\
& 1
\end{aligned}
$$

\section{$1.02[0.7-1.6]$}

1

$1.6^{*}[1.1-2.2]$

1.4 [0.9-2.0]

1.3 [0.9-1.7]

$1.4[0.8-2.3]$

1

1

$1.2[0.9-1.6]$

$1.2[0.9-1.8]$

1

1

$2.8 * * *[1.6-4.8]$

$1.5[0.97-2.4]$

$\begin{array}{ll}1.7[0.7-4.2] & 2.8 * * *[1.6-4.8] \\ 1.4[0.6-3.2] & 1.5[0.97-2.4] \\ 1 & 1\end{array}$

$2.7 * * *[1.7-4.3]$

$2.3^{* * *}[1.6-3.4]$

$1.8 * *[1.2-2.1]$

1

1

$$
\begin{array}{lll}
8.5^{* * *}[5.2-14] & 4.0^{* * *}[2.3-7.1] & 2.7 * * *[1.8-4.1] \\
3.1 * * *[2.2-4.3] & 1.8^{*}[1.1-3.1] & 1.6^{* *}[1.1-2.1] \\
1 & 1 & 1
\end{array}
$$
primary school

0.97 [0.7-1.4] 1

0.98 [0.7-1.4] 1

$1.4[0.96-2.1]$ 1

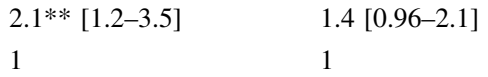

Believe that the building is strong

\begin{tabular}{llll} 
Yes & $1.3[0.9-1.7]$ & $0.8[0.5-1.3]$ & $0.8[0.6-1.1]$ \\
No & 1 & 1 & 1 \\
Attitudes score & & \\
$7-11$ action-stimulating attitudes & $2.0 * * *[1.5-2.6]$ & $1.3[0.9-1.8]$ & $1.3[0.99-1.7]$ \\
$\leq 6$ action-stimulating attitudes & 1 & 1 & 1 \\
\hline
\end{tabular}


Table 3 continued

\begin{tabular}{llll}
\hline & $\begin{array}{l}\text { Scientific explanation } \\
\text { of what an earthquake is } \\
\text { OR; }[95 \% \mathrm{CI}]\end{array}$ & $\begin{array}{l}\text { Mentioned at least two } \\
\text { measures (spontaneously) } \\
\text { OR; [95\% CI }]\end{array}$ & $\begin{array}{l}\text { Knew what to do } \\
\text { in an earthquake } \\
\text { OR; }[95 \% \mathrm{CI}]\end{array}$ \\
\hline $\begin{array}{l}\text { General safety score } \\
\begin{array}{l}\text { Often/always uses } \\
\text { safety belt in car }\end{array}\end{array}$ & $1.2[0.8-1.8]$ & $1.2[0.7-2.0]$ & $1.5[0.9-2.4]$ \\
$\begin{array}{l}\text { No such situation } \\
\text { in the last month }\end{array}$ & $0.8[0.5-1.4]$ & $0.5[0.2-1.1]$ & $1.1[0.8-1.6]$ \\
$\begin{array}{l}\text { Never/seldom uses safety belt } \\
\text { Never }\end{array}$ & 1 & 1 & 1 \\
\hline
\end{tabular}

$* * * p<0.001 ; * * p<0.01 ; * p<0.05$

Table 4 Risk perception

\begin{tabular}{|c|c|c|c|c|}
\hline & & $\begin{array}{l}\text { Totally } \\
\text { agree }(\%)\end{array}$ & $\begin{array}{l}\text { Fifty-fifty } \\
(\%)\end{array}$ & $\begin{array}{l}\text { Totally } \\
\text { disagree }(\%)\end{array}$ \\
\hline \multirow{2}{*}{$\begin{array}{l}\text { The district that I am living in has a lower } \\
\text { earthquake risk than other districts* }\end{array}$} & Bakırköy & 15 & 16 & 69 \\
\hline & Beykoz & 80 & 13 & 7 \\
\hline \multirow{2}{*}{$\begin{array}{l}\text { When compared to other sub-districts, } \\
\text { ours is safer regarding the earthquake risk* }\end{array}$} & Bakırköy & 26 & 24 & 49 \\
\hline & Beykoz & 71 & 19 & 9 \\
\hline \multirow{2}{*}{$\begin{array}{l}\text { In case of an earthquake, my family and/or } \\
\text { I would suffer from the impact* }\end{array}$} & Bakırköy & 56 & 34 & 10 \\
\hline & Beykoz & 41 & 42 & 17 \\
\hline \multirow{2}{*}{$\begin{array}{l}\text { I think that my house is resistant } \\
\text { to earthquakes }\end{array}$} & Bakırköy & 43 & 31 & 27 \\
\hline & Beykoz & 48 & 27 & 25 \\
\hline
\end{tabular}

$* p<0.001, \chi^{2}$

1999 earthquake, 5\% of the buildings totally collapsed (BU 2003), but only $6 \%$ of our respondents could estimate this actual percentage. The frequencies of the responses were almost the same in both of the districts, and there was no significant difference referring to $\chi^{2}$ tests (Fig. 4).

Table 5 presents the findings of the univariate analysis of the factors significantly associated with either perceiving a higher risk for the location of the home or perceiving a higher risk for self and the family, or not believing that the building was strong enough to withstand an earthquake. Experience of only the phenomenon and experience of damage or injury/death due to earthquakes in the family or close circle did not show any significant association with any of the above variables.

\subsubsection{Perceived risk for the location of the home}

Respondents perceiving a higher risk for the location of their homes were those who lived in Bakırköy (high risk area), were women, were married, described their economic status as high and moderate, had a university or higher education degree or had graduated from 
Fig. 4 Respondents' estimates of the percentage of buildings that totally collapsed in Izmit during the 1999 earthquake

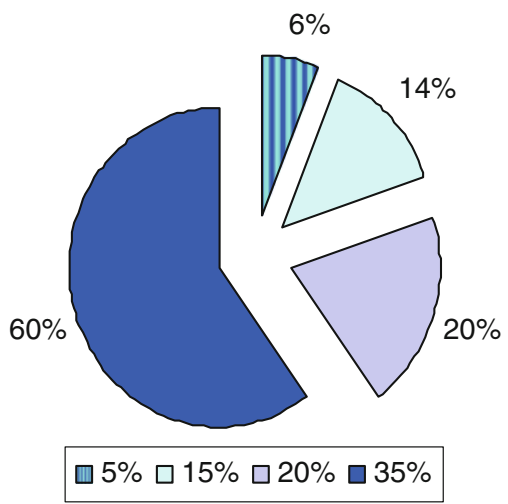

middle or high school, had not participated in solidarity or rescue activities in past earthquakes, could give a scientific explanation about what an earthquake was and knew what to do in an earthquake.

\subsubsection{Perceived risk for self and the family}

Respondents perceiving a higher risk for themselves and their families were those who: lived in Bakırköy, were women, described their economic status as moderate or low, lived in low SEL sub-districts, had the lowest educational level (illiterate/literate/only finished primary school), had not participated in solidarity or rescue activities in previous earthquakes, could not give a scientific explanation about what an earthquake was, whose attitude score was less than 7 or had not travelled on the front seats of a car during the previous month.

\subsubsection{Belief about the strength of the building}

Respondents who did not believe that the building they were living was strong enough to withstand an earthquake were those who were women, were aged 16-34 years, had a child living at home, described their economic status as moderate and low, lived in sub-districts with moderate and low SEL, had the lowest educational level or who had graduated from middle or high school, rented or did not own their homes, could not give a scientific explanation about what an earthquake was, could not spontaneously mention at least two measures, did not know what to do during an earthquake as recommended in information leaflets or whose attitude score was less than 7.

Multivariate logistic regression analysis (Table 6) showed that self-expressed economic status was the only factor that influenced all three risk perception parameters. As could be expected, residence in a high-risk area had an enormous impact on perception of risk for location of the home. Being female and having a higher level of education were other factors influencing the perception of risk for the location of the home. Residence in a higher-risk area and having mentioned at least two measures were also significantly associated with perceiving risk for self and family. In addition to self-expressed economic status, the SEL of the sub-district and renting the home were significantly associated with absence of belief in the strength of the building housing the home. Respondents with an attitudes score of less than 7 also did not believe that their buildings were strong enough to withstand an earthquake. 
Table 5 Univariate analyses of the factors significantly associated with having higher risk perception

\begin{tabular}{|c|c|c|c|c|}
\hline Variable & Value labels & $\begin{array}{l}\text { Perceive risk for the } \\
\text { location of the home } \\
\text { OR1[95\% CI] }\end{array}$ & $\begin{array}{l}\text { Perceive risk for } \\
\text { self and family } \\
\text { OR1 }[95 \% \mathrm{CI}]\end{array}$ & $\begin{array}{l}\text { Perceive risk for } \\
\text { the building } \\
\text { OR1[95\% CI] }\end{array}$ \\
\hline \multirow[t]{2}{*}{$\begin{array}{l}\text { District (location } \\
\text { of home) }\end{array}$} & $\begin{array}{l}\text { Higher-risk district } \\
\text { (Bakırköy) }\end{array}$ & $\begin{array}{l}18 * * * \\
{[13.3-24.5]}\end{array}$ & $\begin{array}{l}1.9 * * * \\
{[1.3-2.7]}\end{array}$ & $\begin{array}{l}1.1 \\
{[0.8-1.4]}\end{array}$ \\
\hline & $\begin{array}{l}\text { Lower-risk district } \\
\text { (Beykoz) }\end{array}$ & 1 & 1 & 1 \\
\hline \multirow[t]{2}{*}{ Gender } & Female & $\begin{array}{l}1.8 * * * \\
{[1.4-2.2]}\end{array}$ & $\begin{array}{l}1.7 * * \\
{[1.2-2.4]}\end{array}$ & $\begin{array}{l}1.4^{*} \\
{[1.1-1.8]}\end{array}$ \\
\hline & Male & 1 & 1 & 1 \\
\hline \multirow[t]{3}{*}{ Age } & 16-34 years & $\begin{array}{l}0.97 \\
{[0.7-1.4]}\end{array}$ & $\begin{array}{l}0.6 \\
{[0.4-1.0]}\end{array}$ & $\begin{array}{l}1.7 * * \\
{[1.2-2.4]}\end{array}$ \\
\hline & $35-54$ years & $\begin{array}{l}0.92 \\
{[0.7-1.2]}\end{array}$ & $\begin{array}{l}0.8 \\
{[0.5-1.2]}\end{array}$ & $\begin{array}{l}1.2 \\
{[0.9-1.6]}\end{array}$ \\
\hline & $\geq 55$ years & 1 & 1 & 1 \\
\hline \multirow[t]{2}{*}{ Marital status } & Married & $\begin{array}{l}1.4^{*} \\
{[1.1-1.9]}\end{array}$ & $\begin{array}{l}1.1 \\
{[0.7-1.6]}\end{array}$ & $\begin{array}{l}1.2 \\
{[0.8-1.6]}\end{array}$ \\
\hline & $\begin{array}{l}\text { Divorced/widowed/ } \\
\text { unmarried }\end{array}$ & 1 & 1 & 1 \\
\hline \multirow[t]{2}{*}{$\begin{array}{l}\text { Presence of child } \\
\text { at home }\end{array}$} & Yes & $\begin{array}{l}0.93 \\
{[0.7-1.2]}\end{array}$ & $\begin{array}{l}1.3 \\
{[0.9-1.8]}\end{array}$ & $\begin{array}{l}1.6^{* *} \\
{[1.2-2.1]}\end{array}$ \\
\hline & No & 1 & 1 & 1 \\
\hline \multirow[t]{3}{*}{ SEL of sub-district } & High & $\begin{array}{l}1.3 \\
{[0.99-1.8]}\end{array}$ & 1 & 1 \\
\hline & Moderate & $\begin{array}{l}0.97 \\
{[0.7-1.3]}\end{array}$ & $\begin{array}{l}1.3 \\
{[0.8-1.9]}\end{array}$ & $\begin{array}{l}3.3 * * * \\
{[2.2-4.8]}\end{array}$ \\
\hline & Low & 1 & $\begin{array}{l}1.9 * * \\
{[1.3-3.0]}\end{array}$ & $\begin{array}{l}3.4 * * * \\
{[2.3-4.9]}\end{array}$ \\
\hline \multirow[t]{3}{*}{$\begin{array}{l}\text { Self-expressed } \\
\text { economic status }\end{array}$} & High & $\begin{array}{l}1.9 * \\
{[1.2-3.1]}\end{array}$ & 1 & 1 \\
\hline & Moderate & $\begin{array}{l}2.2 * * * \\
{[1.4-3.5]}\end{array}$ & $\begin{array}{l}2.2 * * * \\
{[1.5-3.2]}\end{array}$ & $\begin{array}{l}2.7 * * * \\
{[1.8-4.0]}\end{array}$ \\
\hline & Low & 1 & $\begin{array}{l}4.2 * * \\
{[1.8-9.4]}\end{array}$ & $\begin{array}{l}4.0 * * * \\
{[2.3-6.8]}\end{array}$ \\
\hline \multirow[t]{3}{*}{ Educational level } & $\begin{array}{l}\text { University or } \\
\text { higher education }\end{array}$ & $\begin{array}{l}2.2 * * * \\
{[1.6-2.9]}\end{array}$ & 1 & 1 \\
\hline & $\begin{array}{l}\text { Middle school/ } \\
\text { high school }\end{array}$ & $\begin{array}{l}2.1 * * * \\
{[1.6-2.8]}\end{array}$ & $\begin{array}{l}1.3 \\
{[0.9-2.0]}\end{array}$ & $\begin{array}{l}2.7 * * * \\
{[1.8-3.9]}\end{array}$ \\
\hline & $\begin{array}{r}\text { Illiterate/literate/ } \\
\text { primary school }\end{array}$ & 1 & $\begin{array}{l}2.3 * * * \\
{[1.5-3.6]}\end{array}$ & $\begin{array}{l}2.2 * * * \\
{[1.5-3.2]}\end{array}$ \\
\hline \multirow[t]{2}{*}{ Tenure } & Owner & $\begin{array}{l}1.2 \\
{[0.9-1.5]}\end{array}$ & $\begin{array}{l}0.7 \\
{[0.5-1.1]}\end{array}$ & 1 \\
\hline & Tenants and others & 1 & 1 & $\begin{array}{l}1.7 * * * \\
{[1.3-2.3]}\end{array}$ \\
\hline \multirow{2}{*}{$\begin{array}{l}\text { Participated in solidarity } \\
\text { and rescue activities } \\
\text { in previous earthquakes }\end{array}$} & No & $\begin{array}{l}1.7 * * \\
{[1.2-2.3]}\end{array}$ & $\begin{array}{l}1.7 * \\
{[1.1-2.5]}\end{array}$ & $\begin{array}{l}1.3 \\
{[0.9-1.9]}\end{array}$ \\
\hline & Yes & 1 & 1 & 1 \\
\hline
\end{tabular}


Table 5 continued

\begin{tabular}{|c|c|c|c|c|}
\hline Variable & Value labels & $\begin{array}{l}\text { Perceive risk for the } \\
\text { location of the home } \\
\text { OR } 1[95 \% \mathrm{CI}]\end{array}$ & $\begin{array}{l}\text { Perceive risk for } \\
\text { self and family } \\
\text { OR1 }[95 \% \mathrm{CI}]\end{array}$ & $\begin{array}{l}\text { Perceive risk for } \\
\text { the building } \\
\text { OR } 1[95 \% \mathrm{CI}]\end{array}$ \\
\hline \multirow{2}{*}{$\begin{array}{l}\text { Scientific } \\
\text { explanation } \\
\text { of what an } \\
\text { earthquake is }\end{array}$} & Yes & $\begin{array}{l}1.7 * * * \\
{[1.3-2.1]}\end{array}$ & 1 & 1 \\
\hline & No & 1 & $\begin{array}{l}1.5^{*} \\
{[1.03-2.1]}\end{array}$ & $\begin{array}{l}1.4^{*} \\
{[1.1-1.9]}\end{array}$ \\
\hline \multirow{2}{*}{$\begin{array}{l}\text { Mentioned at least } \\
\text { two measures } \\
\text { (spontaneously) }\end{array}$} & Yes & $\begin{array}{l}0.98 \\
{[0.7-1.3]}\end{array}$ & 1 & 1 \\
\hline & No & 1 & $\begin{array}{l}0.8 \\
{[0.5-1.3]}\end{array}$ & $\begin{array}{l}2.1 * * * \\
{[1.4-3.1]}\end{array}$ \\
\hline \multirow[t]{2}{*}{$\begin{array}{l}\text { Knew what to do } \\
\text { in an earthquake }\end{array}$} & Yes & $\begin{array}{l}1.4^{* *} \\
{[1.1-1.8]}\end{array}$ & $\begin{array}{l}1.03 \\
{[0.7-1.5]}\end{array}$ & 1 \\
\hline & No & 1 & 1 & $\begin{array}{l}1.6^{* *} \\
{[1.2-2.0]}\end{array}$ \\
\hline \multirow[t]{2}{*}{ Attitude score } & $\begin{array}{l}\text { Showed at least } 7 \text { action- } \\
\text { stimulating attitudes }\end{array}$ & $\begin{array}{l}0.9 \\
{[0.7-1.2]}\end{array}$ & 1 & 1 \\
\hline & $\begin{array}{l}\text { Showed fewer than } 7 \\
\text { action-stimulating } \\
\text { attitudes }\end{array}$ & 1 & $\begin{array}{l}1.7 * * \\
{[1.2-2.4]}\end{array}$ & $\begin{array}{l}1.7 * * * \\
{[1.3-2.3]}\end{array}$ \\
\hline \multirow[t]{3}{*}{$\begin{array}{l}\text { General safety } \\
\text { action score }\end{array}$} & $\begin{array}{l}\text { Often/always used safety } \\
\text { belt in car in previous } \\
\text { month }\end{array}$ & $\begin{array}{l}1.3 \\
{[0.96-1.9]}\end{array}$ & $\begin{array}{l}1.3 \\
{[0.8-2.0]}\end{array}$ & $\begin{array}{l}0.7 \\
{[0.5-1.0]}\end{array}$ \\
\hline & $\begin{array}{l}\text { No such situation } \\
\text { in previous month }\end{array}$ & $\begin{array}{l}0.8 \\
{[0.5-1.2]}\end{array}$ & $\begin{array}{l}2.6^{* *} \\
{[1.3-5.0]}\end{array}$ & $\begin{array}{l}1.3 \\
{[0.8-2.0]}\end{array}$ \\
\hline & $\begin{array}{l}\text { Never/seldom used } \\
\text { safety belt in car }\end{array}$ & 1 & 1 & 1 \\
\hline
\end{tabular}

*** $p<0.001$; ** $p<0.01$; $p<0.05$; groups with OR 1 are referred to reference groups

\section{Discussion}

There are some limitations to the study that must be addressed. We had to deal with many factors and could not study all of them in detail. Each factor deserves a separate investigation, and many are likely to interact. The aim of the analysis is, however, to explore the effect of factors on each other and the changes in ORs rather than testing a model.

The participants' levels of knowledge about what an earthquake is and how to behave during an earthquake were optimistic, but the level of knowledge about mitigation and preparedness measures was not so promising. Even though the way of asking (spontaneous response versus multiple choices) might be responsible to some extent for this difference, we think that the findings reflect the real situation as we had similar results in a qualitative study in the same study area (Tekeli-Yeşil et al. 2010b).

The media were the leading source of information. A study in Turkey has, however, shown that the media have largely failed in advocating mitigation and preparedness to the public (Dedeoğlu 2008). On the other hand, people had been usually exposed to information from the media, mostly in times of disasters (Tekeli-Yeşil et al. 2010b). Exposure to such information might not necessarily lead individuals to understand, believe or personalize it, and finally to decide on and take action. Mileti and Fitzpatrick (1992) argued 
Table 6 Multivariate analyses of the factors associated with having higher risk perception

\begin{tabular}{|c|c|c|c|}
\hline & $\begin{array}{l}\text { Perceive risk } \\
\text { for location } \\
\text { OR1 }[95 \% \mathrm{CI}]\end{array}$ & $\begin{array}{l}\text { Perceive risk } \\
\text { for self and family } \\
\text { OR1 }[95 \% \mathrm{CI}]\end{array}$ & $\begin{array}{l}\text { Perceive risk } \\
\text { for the building } \\
\text { OR1 }[95 \% \mathrm{CI}]\end{array}$ \\
\hline \multicolumn{4}{|l|}{ Location of the home } \\
\hline Higher-risk area (Bakırköy) & $20 * * *[14-28]$ & $1.8 * *[1.2-2.7]$ & $1.2[0.9-1.7]$ \\
\hline Lower-risk area (Beykoz) & 1 & 1 & 1 \\
\hline \multicolumn{4}{|l|}{ Gender } \\
\hline Female & $1.4 *[1.02-1.9]$ & $1.3[0.9-1.9]$ & $1.2[0.9-1.7]$ \\
\hline Male & 1 & 1 & 1 \\
\hline \multicolumn{4}{|l|}{ Age } \\
\hline 16-34 years & $1.6[0.97-2.7]$ & $0.7[0.4-1.3]$ & $1.6[0.98-2.4]$ \\
\hline $35-54$ years & $1.1[0.8-1.7]$ & $0.9[0.5-1.4]$ & $1.1[0.8-1.6]$ \\
\hline$\geq 55$ years & 1 & 1 & 1 \\
\hline \multicolumn{4}{|l|}{ Marital status } \\
\hline Married & $1.1[0.7-1.6]$ & $1.0[0.7-1.7]$ & $1.1[0.8-1.6]$ \\
\hline Divorced/widowed/unmarried & 1 & 1 & 1 \\
\hline \multicolumn{4}{|l|}{ Presence of child at home } \\
\hline Yes & $1.1[0.8-1.6]$ & $1.3[0.9-2.0]$ & $1.4[0.98-2.0]$ \\
\hline No & 1 & 1 & 1 \\
\hline \multicolumn{4}{|l|}{ Self-expressed economic status } \\
\hline High & $1.6[0.8-3.1]$ & 1 & 1 \\
\hline Moderate & $1.9 *[1.1-3.5]$ & $1.8 * *[1.2-2.8]$ & $1.9 * *[1.2-2.9]$ \\
\hline Low & 1 & $2.9 *[1.2-7.1]$ & $2.5 * *[1.4-4.6]$ \\
\hline \multicolumn{4}{|l|}{ SEL of the sub-district } \\
\hline High & $1.1[0.8-1.6]$ & 1 & 1 \\
\hline Moderate & $1.4[0.9-2.1]$ & $0.99[0.6-1.6]$ & $2.1 * *[1.4-3.2]$ \\
\hline Low & 1 & $1.5[0.9-2.7]$ & $1.9 * *[1.3-3.0]$ \\
\hline \multicolumn{4}{|l|}{ Tenure } \\
\hline Owner & $0.9[0.6-1.2]$ & $0.7[0.5-1.1]$ & 1 \\
\hline Tenants and others & 1 & 1 & $1.5^{*}[1.1-2.0]$ \\
\hline \multicolumn{4}{|l|}{ Educational level } \\
\hline University or higher education & $2.7 * * *[1.6-4.6]$ & 1 & 1 \\
\hline Middle school/high school & $1.7 * *[1.2-2.6]$ & $1.1[0.6-1.6]$ & $1.4[0.9-2.1]$ \\
\hline Illiterate/literate/primary school & 1 & $1.4[0.7-2.6]$ & $1.3[0.8-2.1]$ \\
\hline \multicolumn{4}{|c|}{ Direct experience (participated in rescue and solidarity activities) } \\
\hline No & $1.2[0.8-1.9]$ & $1.3[0.9-2.0]$ & $1.04[0.7-1.5]$ \\
\hline Yes & 1 & 1 & 1 \\
\hline \multicolumn{4}{|c|}{ Scientific explanation of what an earthquake is } \\
\hline Yes & 1 & 1 & 1 \\
\hline No & $1.2[0.8-1.7]$ & $1.1[0.7-1.8]$ & $0.8[0.6-1.2]$ \\
\hline \multicolumn{4}{|c|}{ Mentioned at least two measures (spontaneously) } \\
\hline Yes & 1 & 1 & 1 \\
\hline No & $1.3[0.9-2.0]$ & $2 *[1.2-3.3]$ & $1.3[0.8-2.0]$ \\
\hline
\end{tabular}


Table 6 continued

\begin{tabular}{|c|c|c|}
\hline $\begin{array}{l}\text { Perceive risk } \\
\text { for location } \\
\text { OR1 [95\% CI] }\end{array}$ & $\begin{array}{l}\text { Perceive risk } \\
\text { for self and family } \\
\text { OR1 }[95 \% \mathrm{CI}]\end{array}$ & $\begin{array}{l}\text { Perceive risk } \\
\text { for the building } \\
\text { OR1 }[95 \% \mathrm{CI}]\end{array}$ \\
\hline 1 & 1 & 1 \\
\hline $1.04[0.8-1.5]$ & $0.7[0.5-1.1]$ & $1.2[0.9-1.7]$ \\
\hline 1 & 1 & 1 \\
\hline $1.1[0.8-1.5]$ & $1.4[0.97-2.1]$ & $1.6 * *[1.2-2.1]$ \\
\hline $0.9[0.5-1.3]$ & $1.7[0.8-3.6]$ & $0.9[0.6-1.4]$ \\
\hline $0.9[0.5-1.6]$ & $1.4[0.97-2.1]$ & $1.3[0.8-2.1]$ \\
\hline 1 & 1 & 1 \\
\hline
\end{tabular}

Knew what to do in an earthquake

Yes

No

Attitudes score

7-11 action-stimulating attitudes

$\leq 6$ action-stimulating attitudes

General safety score

Often/always used safety belt in car

No such situation in previous month

Never/seldom used safety belt

$$
1
$$

$* * * p<0.001 ; * * p<0.01 ; * p<0.05$

that the taking of mitigation and preparedness action was more a consequence of people seeking information on their own.

These findings indicate that:

1. preparedness programmes should focus more on information about mitigation and preparedness measures regarding earthquakes;

2. the media can be the main channel for reaching the population in general, but if people are to understand, believe and personalize the information, various methods of risk communication should be used-risk communication is a two-way process, in which the sender and the audience are active participants;

3. the information provided by the media might be more useful if it helped people to question and understand the risk and their ability to cope with it, as well encourage them to take precautions;

4. the Internet also seems to be a promising option for disseminating information.

As we hypothesized, socio-economic considerations (educational and socio-economic levels) were the leading factors associated with enhanced knowledge regarding earthquake risk, followed by location of the home. This finding confirmed once again that disaster management is above all a matter of social and economic development. The attitudes and general safety scores were also moderately associated with enhanced knowledge; findings about these scores indicate that a safety culture in society is an important subject which might play a critical role in coping with various risks in daily life. The media can also support the development of a safety culture in society. Of the demographic characters, age (being in the middle-age group) and presence of child at home showed weak associations. The association between age and giving a scientific explanation about what an earthquake is might be due to the correlations between age and educational and socio-economic levels. Contrary to expectations, there was a negative association between the presence of a child at home and giving a scientific explanation about what an earthquake is. An explanation for this finding might be the socio-economic level of the families with children living at home; those, where children had lived at home, might have lower socio-economic levels. Even though participation in rescue and solidarity activities in previous earthquakes was seen as a significant associate factor in the univariate analysis, none of the earthquake experiences 
were found to be significantly associated with enhanced knowledge in the final model. This result is not paralleled in the existing literature (Burningham et al. 2008; Johnston et al. 1999). Possible explanations for this difference may be the different hazards (flood and volcanic hazards) studied in the papers mentioned and the 1999 earthquakes, which occurred in the same region and affected a large number of people, so that almost all our respondents $(89 \%)$ had experienced an actual earthquake.

In general, respondents were realistic about the risk for the district where they lived. This might be due to wide coverage of information about risk zones in the media and open access to risk maps of Istanbul. The decreasing trend in risk perception of respondents living in Bakırköy when they were asked about their perceptions of risk regarding sub-district, family/self and the home might be due to different reasons. Our qualitative (Tekeli-Yeşil et al. 2010b) study, which was conducted in the same districts, indicates optimistic bias and rationalization as eventual causes of this situation. Similar situations and explanations have also been mentioned by other authors (Burningham et al. 2008; Işeri Say et al. 2005; Johnston et al. 1999). On the other hand, we know from our previous study (Tekeli-Yeşil et al. 2010a) that respondents in Bakırköy were better prepared for an earthquake than respondents living in Beykoz, so that some of the former might feel safer due to the measures they had taken and thus perceive less risk to their properties and to themselves when compared with the respondents living in Beykoz. It might be the other way round for some of the respondents living in Beykoz.

Almost all the respondents overestimated the number of totally collapsed buildings in the 1999 earthquake in Izmit. Images of collapsed buildings and injured people on television after the 1999 earthquakes were the main cause of these false perceptions. In the qualitative study (Tekeli-Yeşil et al. 2010b) mentioned earlier, we found that such false perceptions led to feelings of helplessness and disbelief about protective behaviour among some residents. If the media were to show images of standing buildings as well as of those that have collapsed in future earthquakes, it would demonstrate that not all or even a majority of buildings collapse during even a major earthquake and it is possible to mitigate the damage from earthquakes.

Among the factors associated with high risk perception, only district and participating in solidarity and rescue activities in previous earthquakes remained significant. These findings partly support our hypothesis about risk perception and lead us to think that the explanatory factors that we studied, including socio-economic and demographic factors, experience, knowledge and attitudes, are not sufficient to explain high risk perception. Additional factors, such as individuals' characteristics or emotions and the way information relating to disasters is communicated (e.g., type of message, methods used to disseminate messages), might have a greater influence on risk perception.

In conclusion, analysis reveals that the level of knowledge regarding earthquakes and preparedness for them is promising. It is, however, necessary to improve public knowledge about measures for mitigation of damage and preparedness. The results indicate that future preparedness programmes should target people with lower educational and socio-economic levels. The media could play an effective role in earthquake preparedness, especially if they act in a more responsive manner. Location of the home has a strong influence in above average knowledge, but is much more influential in high risk perception. Nevertheless, considering that almost all parts of Istanbul are at (different levels of) risk of an earthquake and that damage can be attributed to many factors, not only location but also areas at lower risk should not be omitted in preparedness programmes.

Finally, we suggest that further research should be undertaken about the optimal ways of communicating information and their roles in risk perception. 


\section{References}

Armaş I (2008) Social vulnerability and seismic risk perception. Case study: the historic center of the Bucharest Municipality/Romania. Nat Hazards 47(3):397-410

BU (2003) Earthquake risk assessment for the Istanbul metropolitan area final report. Boğaziçi University Press, Istanbul

Burningham K, Fielding J, Thrush D (2008) 'It'll never happen to me': understanding public awareness of local flood risk. Disasters 32(2):216-238

CDO (2009) Deprem ile yasamayi ogrenmeliyiz-We have to learn living with earthquakes. Sivil Savunma Genel Mudurlugu-Civil Defence General Directorate. Available: http://www.ssgm.gov.tr/indir/pdf/ bro_deprem.pdf. Accessed 10.03.2008 2008

Davis MS, Ricci T, Mitchell LM (2005) Perceptions of risk for volcanic hazards at Versuvio and Etna, Italy. Australasian J Disaster Trauma Studies 2005-2001

Dedeoğlu N (2006) Knowledge, attitude and practice of residents of Antalya, Turkey about earthquake preparedness. In: International disaster reduction conference, 27 August-1 September 2006, Davos, Switzerland

Dedeoğlu N (2008) Role of the turkish news media in disaster preparedness 2008

EM-DAT (2009) The OFDA/CRED International Disaster Database. Université catholique de LouvainBrussels-Belgium. Available www.emdat.be. Accessed 26 August 2009

Fişek O, Yeniçeri N, Müderrisoğlu S, Özkarar G (2003) Integrated decision support systems for disaster management in Turkey: Final report of the psychosocial model. Boğaziçi University, CENDIM, Bebek

Ho M-C, Shaw D, Lin S, Chiu Y-C (2008) How do disaster characteristics influence risk perception? Risk Anal 28(3):635-643

Hurnen F, McClure J (1997) The effect of increased earthquake knowledge on perceived preventability of earthquake damage. Australasian J Disaster Trauma Stud

Işeri Say A, İnelmen K, Kabasakal H (2005) Örgütlü Katılım ve Afet Yönetimi Etkileşimi. Öneri 6(23):9-18

Johnston DM, Bebbington MS, Lai C, Houghton BF, Paton D (1999) Volcanic hazard perceptions: comparative shifts in knowledge and risk. Disaster Prevent Manage 8(2):118-126

Kalaça S, Aytekin BA, Çalı Ş (2007) Istanbul'da Depreme Karşı Bireysel Düzeyde Önlem Almayı Belirleyen Faktörler. In: 11th National Public Health Congress, 23-26 October 2007, Denizli, Türkiye

Kasperson RE, Renn O, Slovic P et al (2000) The social implication of risk: a conceptual framework. In: Slovic P (ed) The perception of risk. Earthscan Publications, London, pp 232-245

Lehman DR, Taylor SE (1987) Date with an earthquake: coping with a probable, unpredictable disaster. Personal Soc Psychol Bull 13(4):546-555

Lin S, Shaw D, Ho M-C (2008) Why are flood and landslide victims less willing to take mitigation measures than the public? Nat Hazards 44:305-314

Lindell MK (1994) Perceived characteristics of environmental hazards. Int J Mass Emerg Disasters 12(3):303-326

Lindell MK, Prater CS (2000) Household adoption of seismic hazard adjustments: a comparison of residents in two states. Int J Mass Emerg Disasters 18(2):317-338

Lindell M, Whitney D (2000) Correlates of household seismic hazard adjustment adoption. Risk Anal 20(1):13-25

Mileti DS, Fitzpatrick C (1992) The causal sequence of risk communication in the Parkfield earthquake prediction experiment. Risk Anal 12(3):393-400

Parsons T, Toda S, Stein R, Barka A, Dieterich J (2000) Heightened odds of large earthquakes near Istanbul: an interaction-based probability calculation. Science 288(5466):661-665

Paton D, Millar M, Johnston D (2001) Community resilience to volcanic hazard consequences. Nat Hazards 24(2):157-169

Slovic P, Fischhoff B, Lichtenstein S (2000) Rating the risk. In: Slovic P (ed) The perception of risk. Earthscan Publications, London, pp 104-120

Solberg C, Rossetto T, Hoffe H (2010) The social psychology of seismic hazard adjustment: re-evaluating the international literature. Nat Hazards Earth Syst Sci 10:1663-1677

Tekeli-Yeşil S, Dedeoğlu N, Braun-Fahrlaender C, Tanner M (2010a) Factors that motivate people to take precautionary actions for an expected earthquake in Istanbul. Risk Anal 30(8):1181-1195

Tekeli-Yeşil S, Dedeoğlu N, Tanner M, Braun-Fahrlaender C, Obrist B (2010b) Individual preparedness and mitigation actions for a predicted earthquake in Istanbul. Disasters 34(4):910-930

Weinstein ND (1989) Effects of personal experience on self-protection behaviour. Psychol Bull 105(1):31-50 